\title{
Pancreatic-carcinoma-cell-derived pro-angiogenic factors can induce endothelial-cell differentiation of a subset of circulating CD34+ progenitors
}

\author{
Barbara Vizio ${ }^{1}$, Fiorella Biasi ${ }^{2}$, Tiziana Scirelli ${ }^{1}$, Anna Novarino ${ }^{3}$, Adriana Prati ${ }^{1}$, Libero Ciuffreda ${ }^{3}$,
} Giuseppe Montrucchio ${ }^{1}$, Giuseppe Poli ${ }^{2}$ and Graziella Bellone ${ }^{1 *}$

\begin{abstract}
Background: $\mathrm{CD}_{4} 4^{+}$progenitor cells comprise both hematopoietic and endothelial progenitor cells. Recent studies suggest that circulating endothelial progenitor cells are recruited into the angiogenic vascular system of several cancers, including pancreatic carcinoma, and that they correlate with clinical progress. However, whether endothelial progenitor cell mobilization occurs in response to cytokine release by tumor cells is still unclear.

Methods: The chemotactic- and/or differentiating-activities of the poorly-differentiated pancreatic carcinoma cell line PT45, and of the immortal H6c7 cell line, a line of near-normal pancreatic duct epithelial cells, on endothelial progenitor cells were investigated in vitro using circulating $\mathrm{CD}_{3} 4^{+}$as model.

Results: The study showed that Vascular Endothelial Growth Factor produced by PT45 cells and, at lesser extent, by $\mathrm{H} 6 \mathrm{c} 7$ cells, predominantly chemoattract peripheral blood $\mathrm{CD}_{3} 4^{+}$expressing the type 2 relative receptor. Addition of PT45-conditioned medium to $\mathrm{CD}_{3} 4^{+}$cells, cultured under conditions supporting myeloid cell development, diverted the differentiation of a subset of these progenitor cells into cells expressing endothelial cell markers, such as CD146, CD105, VE-cadherin and von Willebrand Factor-related antigen. Moreover, these endothelial-like cells formed capillary networks in vitro, chiefly through the release of Angiopoietin-1 by PT45 cells.

Conclusions: The results demonstrate that pancreatic-carcinoma cells potentially attract circulating endothelial progenitor cells to the tumor site, by releasing high levels of pro-angiogenic factors such as Vascular Endothelial Growth Factor and Angiopoietin-1, and may direct the differentiation of these cell subsets of the $\mathrm{CD} 34^{+}$cell population into endothelial cells; the latter cells may become a component of the newly-formed vessels, contributing to angiogenesis-mediated tumor growth and metastasis.
\end{abstract}

Keywords: CD34 ${ }^{+}$cells, Endothelial progenitor cells, Pancreatic carcinoma, H6c7 cells, Angiogenic growth factors, Tumor neoangiogenesis

\section{Background}

It is well known that, in order to develop in size and metastatic potential, tumors must make an "angiogenic switch"; they achieve this by perturbing the local balance of pro-angiogenic and anti-angiogenic factors [1]. When positive angiogenic regulators overcome the effect of negative angiogenic molecules, the tumor acquires angiogenic capability, leading to the formation of new blood vessels.

\footnotetext{
* Correspondence: graziella.bellone@unito.it

'Department of Medical Sciences, University of Turin, Turin, Italy

Full list of author information is available at the end of the article
}

Tumor cells may induce angiogenesis directly, by releasing pro-angiogenic factors, and/or indirectly, by attracting inflammatory cells that, in turn, release angiogenic stimuli [2]. The number of factors known to be capable of eliciting an angiogenic response is steadily increasing. Vascular Endothelial Growth Factor (VEGF) is considered a master regulator of the angiogenic cascade, and is thought to promote endothelial cell differentiation, migration, proliferation, and survival [3]. The finding that a number of malignant human tumors, including lung, breast, gastrointestinal tract, ovary, and colon, produce VEGF [4-8], and that the inhibition of

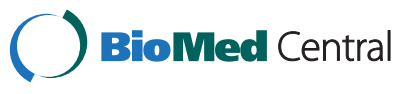


VEGF-induced angiogenesis significantly inhibits tumor growth in vivo [9], point to its possessing clinical significance in tumor growth.

Pancreatic carcinoma is a biologically-aggressive tumor that has an early propensity to spread locally and metastasize distally. While not grossly vascular, this tumor often exhibits enhanced foci of endothelial cell proliferation, and over-expresses multiple proangiogenic factors $[10,11]$. In particular, a positive correlation between blood vessel density, tumor VEGF-A isoform levels, and disease progression has been reported in pancreatic carcinoma [12-14].

The formation of new capillaries to provide an oxygen supply for tumors was, until recently, believed to be mediated by the sprouting or co-option of pre-existing neighboring vessels [15].

However, increasing evidence now suggests that circulating endothelial progenitor cells (EPC), normally involved in maintaining vascular integrity, can also home in to the tumor site and contribute to the de novo formation of blood vessels [16].

In previous studies we found that VEGF expression in pancreatic carcinoma cell lines is both high and inversely correlated with differentiation status [10]. Moreover, EPC and VEGF-A plasma levels were found to be significantly elevated in the blood of pancreatic carcinoma patients, to be positively associated with disease stage, and inversely associated with overall survival [17]. These finding suggest that microenvironmental conditions favoring mobilization of EPC, which are key contributors to the early steps in neoplastic vascularization [18], might enable the tumor to grow and metastasize faster. However, there is ongoing debate about the distribution, contribution, origin, and differentiation of EPC in tumor vasculogenesis.

The present research aimed to investigate the ability of pancreatic carcinoma cells to attract and skew the differentiation of $\mathrm{CD} 4^{+}$progenitor cells toward endothelial cells, by releasing pro-angiogenic factors. We show that PT45 cells, as normal pancreatic ductal epithelial cells, promote the recruitment of $\mathrm{CD} 34^{+}$cells. Moreover, when cultured under conditions that facilitate myeloid-cell development, $\mathrm{CD}_{4} 4^{+}$cells are instead redirected by the tumor to differentiate into endothelial cells. The resulting cells resemble endothelial cells phenotypically, as well as functionally, as is shown by the fact they can be stimulated to reorganize into cord structures. Tumor-derived VEGF contributed significantly to the chemoattractant activity, whereas Angiopoietin (Angio)-1 chiefly provided the instructive differentiation signal.

\section{Materials and methods Ethics Statement}

The Hemocomponent Production and Validation Center (Centro per la Produzione e Validazione di Emoprodotti,
CPVE) (Turin, Italy) Ethics Committee has waived the need for consent, due to the fact the blood donor material used was fully anonymized. The study did not involve human beings directly and, according to article 2 comma I, letter a) and article 6 of Italian Legislative Decree dated 24. 06. 2003, no. 211, and article 1, comma I of Italian Ministry of Health Decree dated 12. 05. 2006, did not require an opinion from the Ethical Committee.

\section{Cell lines}

The pancreatic-cell line PT45 (kindly provided by Dr. M.F. Di Renzo, Department of Biomedical Sciences and Human Oncology, University of Turin, Italy) [19] was grown in RPMI 1640 medium supplemented with 10\% fetal calf serum (FCS) (Merck Millipore, Billerica, MA). The cell line was routinely screened for mycoplasma contamination, using the Hoechst dye H33258 (Sigma Aldrich, St. Louis, MO, USA). Immortalized human pancreatic ductal epithelial cells HPDE6-E6E7 (H6c7), established after transduction of the HPV16-E6E7 genes into primary cultures of normal pancreatic duct epithelial cells, were generously provided by Dr. Ming-Sound Tsao, (Ontario Cancer Institute/Princess Margaret Hospital, University Health Network, Toronto, Canada) [20]. The cell line demonstrates a near-normal genotype and phenotype of pancreatic duct epithelial cells [21]. The H6c7 cells were grown in serum free Keratinocyte Basal Medium (KBM) fortified with growth factors, cytokines, and supplements (SingleQuots ${ }^{\mathrm{Tu}}$ Kit) (Lonza Group Ltd, Basel, Switzerland).

In order to obtain serum-free conditioned medium (CM), PT45 and H6c7 cells were trypsinized, extensively washed with phosphate-buffered saline (PBS), and seeded at $3 \times 10^{5} /$ $\mathrm{ml}$, in $5 \mathrm{ml}$ of serum-free RPMI 1640 medium containing $0.25 \%$ fatty-acid-free bovine serum albumin fraction $\mathrm{V}$ (Sigma Aldrich) and KBM, respectively. After 48-hour incubation in a humidified atmosphere containing $5 \% \mathrm{CO}_{2}$, $\mathrm{CM}$ was collected after centrifugation, and stored at $-20^{\circ} \mathrm{C}$ until use.

\section{Human umbilical vein endothelial cells (HUVEC)}

HUVEC were obtained from Lonza Group Ltd and propagated in EndoGRO medium (Merck Millipore).

\section{Isolation of circulating $\mathrm{CD} 34^{+}$progenitor cells}

Low-density peripheral blood mononuclear cells (PBMC) were isolated from normal buffy coats received from the CPVE, by centrifugation at $250 \mathrm{~g}$ over Ficoll-Hypaque. $\mathrm{CD}^{+}{ }^{+}$cells were purified using the CD34-isolation miniMACS (magnetic cell sorting) kit (Miltenyi, Bergisch Gladbach, Germany) or the EasySep human $\mathrm{CD}^{+} 4^{+}$selection kit (StemCell Technologies, Vancouver, BC, Canada), following the manufacturers' directions. In both cases, the 
purity of the isolated $\mathrm{CD} 34^{+}$cells was verified by flow cytometry, and was in the $89 \%-98 \%$ range.

\section{RNA extraction and real time reverse transcription (RT)-PCR}

RNA was extracted from PT45 cells, H6c7 cells, 19-daycultured $\mathrm{CD}^{+} 4^{+}$cells in the absence or presence of PT45-CM, and from appropriate positive controls, comprising the colon carcinoma cell line DLD-1, the hepatocellular carcinoma cell line HepG2, bone marrow (BM) stroma, and HUVEC, using TRIzol Reagent (Invitrogen, Carlsbad, CA) and following the manufacturer's instructions. To remove traces of genomic DNA, total RNA (3 $\mu \mathrm{g}$ ) was treated with DNase I (Invitrogen) and reverse-transcribed to cDNA, using SuperScript II Reverse Transcriptase (Invitrogen). Lastly, cDNA specimens were diluted with $130 \mu \mathrm{l}$ of $\mathrm{H}_{2} \mathrm{O}$.

Real Time RT-PCR analysis was run on the $\mathrm{iCycler} \mathrm{iQ}$ system (Bio-Rad, Hercules, CA) by the SYBR green I dye detection method. Amplification of $\beta$-actin, VEGF-A, Angio-1, Angio-2, SDF-1A (CXCL12), VE-cadherin, von Willebrand factor ( $\nu W F)$, VEGF receptor (R)-1 (flt-1) and $V E G F R-2(f l k-1 / K D R)$ transcripts was run in duplicate, in a PCR optical 96-well reaction plate (Bio-Rad); the PCR mixture in each well contained cDNA corresponding to $100 \mathrm{ng}$ of total RNA, the relevant sequencespecific primers (150 nM for $\beta$-actin and $300 \mathrm{nM}$ for the other cytokines) and $1 \mathrm{X}$ iQ SYBR Green Supermix (Bio-Rad). Table 1 lists primer sequences, designed using Beacon Designer 5 Software (Bio-Rad) to be cDNA specific, and to work under equivalent reaction conditions. Primers were synthesized by Invitrogen and reconstituted in nuclease-free water before use. Negative PCR controls without cDNA template, and a positive control sample with a known cycle threshold value $(\mathrm{Ct})$, were included in each assay. Optimized thermal cycling conditions were as follow: $5 \mathrm{~min}$ at $95^{\circ} \mathrm{C}$ followed by 40 cycles of $15 \mathrm{~s}$ at $95^{\circ} \mathrm{C}$ and $1 \mathrm{~min}$ at $60^{\circ} \mathrm{C}$ (two-step PCR). Specificity of the PCR products was confirmed by the melting curve program at the end of the reaction $\left(55^{\circ} \mathrm{C}\right.$ to $95^{\circ} \mathrm{C}$ with a heating rate of $0.5^{\circ} \mathrm{C} / 10 \mathrm{sec}$ and continuous fluorescence measurements). PCR efficiency $(E)$ was determined by the method described by Ramakers et al. [22] using the iCycler iQ software. For each sample, the $\mathrm{Ct}$ was acquired using the Fit Point Method [23]. Mean normalized gene expression (MNE) was calculated from the following formula: $\mathrm{NE}=E_{\text {reference }}$ Ct reference $/ E_{\text {target }}$ Ct target. The statistical significance of the difference in mRNA expression of the receptors examined, in PT45-CM treated- and untreated-CD34 ${ }^{+}$cells, was analyzed using the Relative Expression Software Tool (REST) for group-wise comparison, and statistical analysis of relative expression results in real-time PCR [24]. This software package calculates an expression ratio relative to the control group (untreated-CD34 ${ }^{+}$cells) normalized to a reference gene $(\beta$-actin). The mRNA expression data for $\beta$-actin showed no significant difference between untreated- and PT45-CM treated- $\mathrm{CD}_{4}{ }^{+}$cells. The expression ratio $(\mathrm{R})$ is: $\mathrm{R}=E_{\text {target }} \Delta \mathrm{Ct}$ target (mean untreated-mean treated sample) $/ E_{\text {reference }} \Delta \mathrm{Ct}$ reference (mean untreated-mean treated sample)

\section{Evaluation of VEGF-A, CXCL12, Angio-1, and Angio-2}

Secreted levels of VEGF-A, CXCL12, Angio-1, and Angio-2 were determined in cell-free CM from the pancreaticcarcinoma cell lines PT45 and H6c7, using commerciallyavailable ELISA kits (R\&D Systems, Minneapolis, MN, and

Table 1 Primer sequences for housekeeping, cytokine and endothelial marker quantification by real time RT-PCR

\begin{tabular}{|c|c|c|c|}
\hline Primer set & GenBank & Primer sequence & RT-PCR \\
\hline & Accession \# & & $E(\%)$ \\
\hline \multirow[t]{2}{*}{$\beta$-actin } & NM_001101 & $\begin{array}{l}\text { FW -GCG AGA AGA } \\
\text { TGA CCC AGA TC- }\end{array}$ & \\
\hline & & $\begin{array}{l}\text { RW -GGA TAG CAC } \\
\text { AGC CTG GAT AG- }\end{array}$ & 100 \\
\hline \multirow[t]{2}{*}{ VEGF-A } & NM_001025366 & $\begin{array}{l}\text { FW -ATG AGG ACA } \\
\text { CCG GCT CTG ACC A- }\end{array}$ & \\
\hline & & $\begin{array}{l}\text { RW -AGG CTC CTG } \\
\text { AAT CTT CCA GGC A- }\end{array}$ & 94.5 \\
\hline \multirow[t]{2}{*}{ Angio-1 } & NM_001146 & $\begin{array}{l}\text { FW -GAG GCA CGG } \\
\text { AAG GAG TGT GCT G- }\end{array}$ & \\
\hline & & $\begin{array}{l}\text { RW -CGG CGC TGA } \\
\text { TTG CTG CAC CCT A- }\end{array}$ & 92.0 \\
\hline \multirow[t]{2}{*}{ Angio-2 } & NM_001147 & $\begin{array}{l}\text { FW -AAA AGC TGA } \\
\text { CAC AGC CCT CCC A- }\end{array}$ & \\
\hline & & $\begin{array}{l}\text { RW -ACT GCT GTG TTC } \\
\text { TCT CCA GGC A- }\end{array}$ & 86.0 \\
\hline \multirow[t]{2}{*}{ CXCL12 } & NM_000609 & $\begin{array}{l}\text { FW -ATG CCC ATG } \\
\text { CCG ATT CTT CG- }\end{array}$ & \\
\hline & & $\begin{array}{l}\text { RW -GCC GGG CTA } \\
\text { CAA TCT GAA GG- }\end{array}$ & 100 \\
\hline \multirow[t]{2}{*}{ VE-cadherin } & NM_001795 & $\begin{array}{l}\text { FW -GGT CCC TGA } \\
\text { ACG CCC TGG TAA- }\end{array}$ & \\
\hline & & $\begin{array}{l}\text { RW -GGA GTG GAG TAT } \\
\text { GGA GTT GGA GCA- }\end{array}$ & 95.5 \\
\hline \multirow[t]{2}{*}{$\begin{array}{l}\text { von Willebrand } \\
\text { Factor (vWF) }\end{array}$} & NM_000552 & $\begin{array}{l}\text { FW -GCC TGC TTC } \\
\text { TGC GAC ACC ATT G- }\end{array}$ & \\
\hline & & $\begin{array}{l}\text { RW -GCC ACT CAC ACT } \\
\text { CAT ACC CGT TCT- }\end{array}$ & 96.2 \\
\hline \multirow[t]{2}{*}{ Flt1 (VEGF-R1) } & NM_002019 & $\begin{array}{l}\text { FW -CAC GCA GGA } \\
\text { CCA GTT TGA TTG AG- }\end{array}$ & \\
\hline & & $\begin{array}{l}\text { RW -GCT AGA GGA CTC } \\
\text { CCG AGA TGT TG- }\end{array}$ & 96.7 \\
\hline \multirow[t]{2}{*}{$\begin{array}{l}\text { Flk-1/KDR(VEGF- } \\
R 2)\end{array}$} & NM_002253 & $\begin{array}{l}\text { FW -GCA GGG GAC } \\
\text { AGA GGG ACT TG- }\end{array}$ & \\
\hline & & $\begin{array}{l}\text { RW -GAG GCC ATC } \\
\text { GCT GCA CTC A }\end{array}$ & 95.3 \\
\hline
\end{tabular}


RayBiotech, Norcross, GA, respectively) following the manufacturers' directions. The minimum detectable doses were below $9 \mathrm{pg} / \mathrm{ml}$ for VEGF-A, below $18 \mathrm{pg} / \mathrm{ml}$ for CXCL12, below $30 \mathrm{pg} / \mathrm{ml}$ for Angio-1, and below $10 \mathrm{pg} / \mathrm{ml}$ for Angio-2.

\section{Cell migration assay}

Cell migration assays were run in transwell plates $(8 \mu \mathrm{m}$ pore size, Costar, Cambridge, MA). Either $\mathrm{CD}^{+} 4^{+}$or HUVEC cell suspension $\left(3 \times 10^{4}\right.$ cells $\left./ \mathrm{ml}\right)$ was added to the upper compartment of the transwell chamber. $30 \%$ of PT45- or of H6c7-CM, as such or pre-treated with neutralizing polyclonal goat antibodies against VEGF-A (Chemicon International, Temecula, CA) and Angio-1 (Sigma Aldrich), or with appropriate irrelevant antibody as control, was added to the lower well of the transwell chamber as chemoattractant. In selected experiments, $\mathrm{CD}^{+}{ }^{+}$cells were also pretreated with an anti-human VEGFR-1/Flt-1 polyclonal goat antibody blocking receptorligand interaction $(25 \mu \mathrm{g} / \mathrm{ml})$ (R\&D Systems). The chambers were incubated for $24 \mathrm{~h}$ at $37^{\circ} \mathrm{C}, 5 \% \mathrm{CO}_{2}$. After removing the cells from the upper side of the membrane, with a cotton swab, migrated cells were fixed and stained with crystal violet dye. Stained cells were visualized and quantified by counting cells in three highpower fields (100X). Data are shown as means \pm SE from three/six separate series of assays.

\section{Proliferation assay}

$\mathrm{CD}_{3}{ }^{+}$cells were seeded in triplicate at a concentration of $5 \times 10^{4}$ cells/well in 96-well plates, in RPMI 1640 medium containing $10 \% \mathrm{FCS}$, in the absence or presence of $30 \%$ of either PT45-CM or H6c7-CM. $50 \mathrm{ng} / \mathrm{ml}$ of human recombinant Stem Cell Factor (SCF) and Fmsrelated tyrosine kinase (FLT)-3 Ligand (PeproTech, Rocky Hill, NJ) was used as control, to activate stem-cell and immature-progenitor-cell cycling. To determine DNA synthesis, after $20 \mathrm{hr}$ incubation, cells were pulsed with triziated-Thymidine $\left({ }^{3} \mathrm{H}\right)$-TdR (Perkin Elmer, $1 \mu \mathrm{Ci}$ / well) for a further $4 \mathrm{hr}$. Cellular DNA was collected on glass fiber filters, and ${ }^{3} \mathrm{H}-\mathrm{TdR}$ incorporation was measured in a $\beta$-counter. Results are expressed as median cpm (count per minute) (range) of two separate experiments.

\section{Differentiation of $\mathrm{CD} 34^{+}$cells}

To determine the effect of tumor-derived soluble factors on $\mathrm{CD}_{34}{ }^{+}$cell differentiation, normal peripheral blood $\mathrm{CD}_{3} 4^{+}$progenitor cells, isolated immunomagnetically as described above, were resuspended in Iscove medium (Merck Millipore) containing 20\% FCS, $10 \mathrm{ng} / \mathrm{ml}$ recombinant Interleukin (IL)-3, $10 \mathrm{ng} / \mathrm{ml} \mathrm{SCF}$, and 50 ng/ml Granulocyte-Macrophage Colony Stimulating Factor (GM-CSF) (PeproTech); they were then seeded in wells of 6-well plates coated with fibronectin, in the absence or presence of 30\% PT45-CM. Cells were allowed to incubate for $15-19$ days at $37^{\circ} \mathrm{C}$ in a $5 \% \mathrm{CO}_{2}$ atmosphere.

\section{Evaluation of acetylated low-density lipoprotein uptake and of binding to Ulex europaeus lectin, by laser scanning confocal microscopy (LSCM)}

To measure the uptake of acetylated low-density lipoprotein, and adherence to Ulex europaeus lectin, CD34 ${ }^{+}$ cells were grown in thick-glass-base dishes (Asahi Techno Glass Co., Singapore). After 15-19 days' culture in the presence of IL-3, SCF, and GM-CSF, with or without $30 \%$ of PT45-CM, cells were incubated for $1 \mathrm{~h}$ at $37^{\circ} \mathrm{C}$ in RPMI $+10 \%$ FCS containing $10 \mu \mathrm{g} / \mathrm{ml} 1,1$-dioctadecyl-3,3,3,3-tetramethylindocarbocyanine-labeled acetylated low-density lipoprotein (Dil-AcLDL; Molecular Probes, Eugene, USA) and fixed with $2 \%$ paraformaldehyde for $10 \mathrm{~min}$. After washing, fluorescein isothiocyanate (FITC)conjugated Ulex europaeus lectin (Sigma Aldrich) was added at a concentration of $10 \mu \mathrm{g} / \mathrm{ml}$ in PBS, and cells were incubated for $1 \mathrm{~h}$ at room temperature in the dark. HUVEC were used as positive control. Direct fluorescence staining was analyzed by LSCM (Zeiss LSM 510; Carl Zeiss SpA, Arese, Milan, Italy) equipped with a Zeiss inverted microscope with a "plan neofluar" lens. Exciting light intensity, black level, and photomultiplier gain were adjusted on control specimens; the same settings were used to scan experimental slides. The laser band of excitation was $488 / 543 \mathrm{~nm}$; the emission was set with a $560 \mathrm{~nm}$ long-pass filter for Dil-AcLDL (red) and a 505-530 nm band pass for FITC-conjugated Ulex europaeus lectin (green). The fluorescent images were processed using LSCM 510 Image Examiner software from Zeiss.

\section{Flow cytometry analysis}

Expression of endothelial cell markers CD146 and CD105 was analyzed on untreated and on PT45-CMtreated $\mathrm{CD}_{3}{ }^{+}$cells, after 19 days' culture, in the presence of GM-CSF, IL-3 and SCF. The cells were stained with FITC-conjugated CD146 (Chemicon International) and CD105 (Millipore) mouse monoclonal antibodies for $30 \mathrm{~min}$ at $4^{\circ} \mathrm{C}$. After washing, cells were analyzed by flow cytometry in a Coulter Epics IV Cytometer (Beckman Coulter, Inc., Fullerton, CA). Results are expressed as percentages of positive cells. Statistical analyses were based on at least 30,000 events gated on the population of interest.

\section{Immunohistochemistry}

PT45 cells, and 19-day cultured CD34 ${ }^{+}$cells in the presence of IL-3, SCF and GM-CSF, with or without 30\% of PT45-CM, were harvested, cytospinned and fixed in acetone. After 5 min exposure to $0.3 \%$ solution of $\mathrm{H}_{2} \mathrm{O}_{2}$, 
to inhibit endogenous peroxidase activity, cytospins were treated for $1 \mathrm{~h}$ with a blocking buffer (10\% normal mouse/rabbit/goat serum in PBS) to prevent nonspecific staining, incubated overnight at $4^{\circ} \mathrm{C}$ with the primary antibodies listed in Table 2, and then washed twice with PBS for 5 min each time. For negative controls, the primary antibodies were replaced with appropriate non-immune sera. The slides were then treated with appropriate biotinylated secondary antibodies, followed by incubation with avidin-biotin peroxidase complex solution, for $30 \mathrm{~min}$, and diaminobenzidine tetrahydrochloride as chromogen (Dako LSAB ${ }^{\oplus}$ kit, Dako, Glostrup, Denmark). The slides were finally counterstained with Mayer's hematoxylin for 5 seconds, dehydrated, and mounted in Clarion (Biomeda, Foster City, California, USA).

\section{In vitro angiogenesis assays}

Matrigel basement membrane matrix (Becton Dickinson, Franklin Lakes, NJ USA) was added $(100 \mu \mathrm{l})$ to a 96-well plate and allowed to polymerize. HUVEC or CD34 $4^{+}$ cells, cultured for 19 days in IL-3, SCF and GM-CSF, in the presence or absence of $30 \%$ of PT45-CM, were resuspended in Medium 199 (Millipore) and 0.5\% FCS $\left(2 \times 10^{4}\right.$ cells $\left./ 1 \mathrm{ml}\right)$ in the presence of $30 \%$ of PT45-CM, pre-treated or not with neutralizing antibodies against VEGF or Angio-1, or with the appropriate irrelevant antibody; they were then plated $(100 \mu \mathrm{l})$ on the top of the solidified matrix solution and incubated at $37 \mathrm{C}$ for $24 \mathrm{hr}$. Tubule formation was visualized using an inverted-light microscope with a $20 \mathrm{X}$ objective (Zeiss), and images of ten random fields were captured using a digital camera. Each cell within the optical field was counted, and this number referred to as the "total number of cells per field". The angiogenic potential was quantified from the following formula:

Angiogenic score $=[($ number of sprouting cells $\mathrm{x} 1]+$ number of connected cells $\mathrm{x} 2+$ number of polygons $\mathrm{x}$ 3)]/ Total number of cells per field. The final individual score derived from the formula was then taken as one value in a total of ten, with median [range] represented against other treatment conditions.

Table 2 Antibodies and immunohistochemical procedures

\begin{tabular}{llll}
\hline Reactivity & Antibody & Source & Antibody \\
\hline & Species & & Dilution \\
VEGF-A & Rabbit & $\begin{array}{l}\text { Santa Cruz Biotech., Santa } \\
\text { Cruz, CA }\end{array}$ & $1: 20$ \\
Angio-1/4 & Goat & Santa Cruz Biotech & $1: 200$ \\
Angio-2 & Goat & Santa Cruz Biotech & $1: 200$ \\
CXCL12 & Rabbit & Santa Cruz Biotech & $1: 30$ \\
VE-cadherin & Mouse & Santa Cruz Biotech & $1: 100$ \\
vWF related & Rabbit & Shandon Immunon, & $1: 20$ \\
antigen & & Pittsburgh, PA & \\
\hline
\end{tabular}

\section{Statistical analysis}

To assess statistically-significant differences between datasets, Student's $t$ tests for paired samples, or Mann-Whitney Rank Sum tests, were performed using SigmaStat software (Jandel Scientific, San Rafael, CA).

\section{Results}

Expression of angiogenic factor mRNA in PT45 and in $\mathrm{H} 6 \mathrm{c7}$ cells by real time RT-PCR

Steady-state angiogenic factor mRNA levels were quantitatively assessed in PT45 and H6c7 cell lines, using realtime RT-PCR, and normalized gene expressions were compared (Table 3). Both cell lines expressed similar levels of VEGF mRNA. Conversely, the Angio-1 transcript was expressed at a markedly lower level in H6c7 cells than in PT45 cells (fourteen times lower). Both cell lines were found to be negative for Angio-2 mRNA. The CXCL12 message was expressed at a very low level in PT45 cells and not at all in H6c7 cells.

\section{Expression of VEGF-A, Angio-1, Angio-2 and CXCL12 proteins by PT45 and by $\mathrm{H} 6 \mathrm{c7}$ cells}

The release of VEGF-A, Angio-1, Angio-2, and CXCL12 proteins was evaluated in PT45-CM and in H6c7-CM by ELISA. As shown in Figure 1 (upper panel), significantly higher levels of VEGF-A and Angio-1 were detected in PT45-CM than in H6c7-CM (mean $\pm \mathrm{SE}$ : $1413.8 \pm$ $311.6 \mathrm{pg} / \mathrm{ml}$ vs. $971.3 \pm 186.5 \mathrm{pg} / \mathrm{ml}, \mathrm{p}=0,042$; mean \pm $\mathrm{SE}: 362.9 \pm 37.9 \mathrm{pg} / \mathrm{ml}$ vs. $224.4 \pm 33.14 \mathrm{pg} / \mathrm{ml}, \mathrm{p}=$ 0,0267, respectively). Consistently with mRNA expression, Angio-2 and CXCL12 levels were undetectable by ELISA in either cell supernatants. Immunohistochemical analysis of these molecules, run on PT45 cell cytospins using specific antibodies, detected intense staining for VEGF-A and Angio-1 in the cytoplasm of the majority of PT45 cells, while Angio-2 and CXCL12 expression was negligible (Figure 1, lower panel), consistently with the ELISA results. The combined expression of VEGF-A and Angio-1 suggests that the poorly-differentiated PT45 cells possess higher vascular remodeling capacity than do H6c7 cells.

Table 3 Levels of angiogenic factor mRNA in PT45 and H6c7 cells

\begin{tabular}{lcc}
\hline Gene & \multicolumn{2}{c}{ mRNA levels (relative to $\beta$-actin) } \\
\cline { 2 - 3 } & \multicolumn{2}{c}{ PT45 cells H6c7 cells } \\
\hline VEGF-A & $0,016821^{\mathrm{a}}$ & 0,016270 \\
Angio-1 & 0,000083 & 0,000006 \\
Angio-2 & $\mathrm{nd}^{\mathrm{b}}$ & $\mathrm{nd}$ \\
CXCL12 & 0,000001 & $\mathrm{nd}$ \\
\hline
\end{tabular}

${ }^{\mathrm{a}}$ Mean normalized gene expression (MNE).

bot detectable. 


\section{Do PT45-CM and H6c7-CM chemoattract circulating $\mathrm{CD} 34^{+}$?}

To test this hypothesis, since production of endothelial chemotactic factors, such as VEGF-A and Angio-1 [25], was detected in PT45-CM and in H6c7-CM, the supernatants were assessed for in vitro chemotaxis of circulating $\mathrm{CD}_{34}{ }^{+}$cells, which are known to express the relative receptors [26]. HUVEC were used as positive controls. As shown in Figure 2, both HUVEC and CD34 ${ }^{+}$cells demonstrated a significant chemotactic response, both to PT45-CM and to HPDE-CM, although in the latter case to a lesser extent $\left(\mathrm{CD} 34^{+}\right.$cells migrated/HPF: PT45-CM, $16.333 \pm 3.082$ vs. H6c7-CM, 9.667 \pm 3.41 , $p=0.003)$. Since factors secreted by PT45 and H6c7 cells are also likely to have an effect on cell proliferation, to ensure that the results are a true measure of cell migration, $\mathrm{CD}_{3}{ }^{+}$cells were cultured for $24 \mathrm{hr}$ in the presence or absence of PT45-CM or H6c7-CM, and DNA-synthetic activity was assessed in terms of ${ }^{3} \mathrm{H}$-TdR uptake. No significant difference in DNA synthesis ( $p>0.05$ ) was observed between untreated and CM- treated $\mathrm{CD}_{34}{ }^{+}$cells [median cpm (range): control 438 (334-527); PT45-CM 395 (296-478); H6c7-CM 380 (297-502)]. In the presence of the mitogenic factors SCF and FLT-3, the DNA-synthetic activity of CD34 ${ }^{+}$cells slightly increased over control values, but not to a statistically-significant extent (median cpm (range): 531 (344-727) vs. 438 (334-527), p=0,400). To determine the factor responsible for chemoattraction of $\mathrm{CD}_{4} 4^{+}$ cells, the supernatants were pre-treated with isotypecontrol or with neutralizing VEGF-A and Angio-1 antibodies. Treatment with antibodies neutralizing Angio-1 activity only partially reduced the $\mathrm{CD} 34^{+}$migration induced by either CM (\% CD34 ${ }^{+}$cells migration inhib-

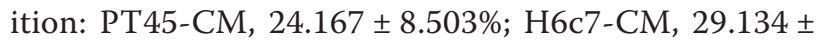
$13.429 \%)$, whereas when the neutralizing VEGF-A antibody was added, migration was almost entirely inhibited (\% CD34 ${ }^{+}$cells migration inhibition: PT45CM, $75.167 \pm 25.87 \%$; H6c7-CM, $59.476 \pm 17.359 \%)$. By contrast, exposure to a neutralizing VEGF-R1 polyclonal antibody did not significantly decrease CD34 ${ }^{+}$ recruitment (\% $\mathrm{CD}^{+} 4^{+}$cells migration inhibition: PT45-
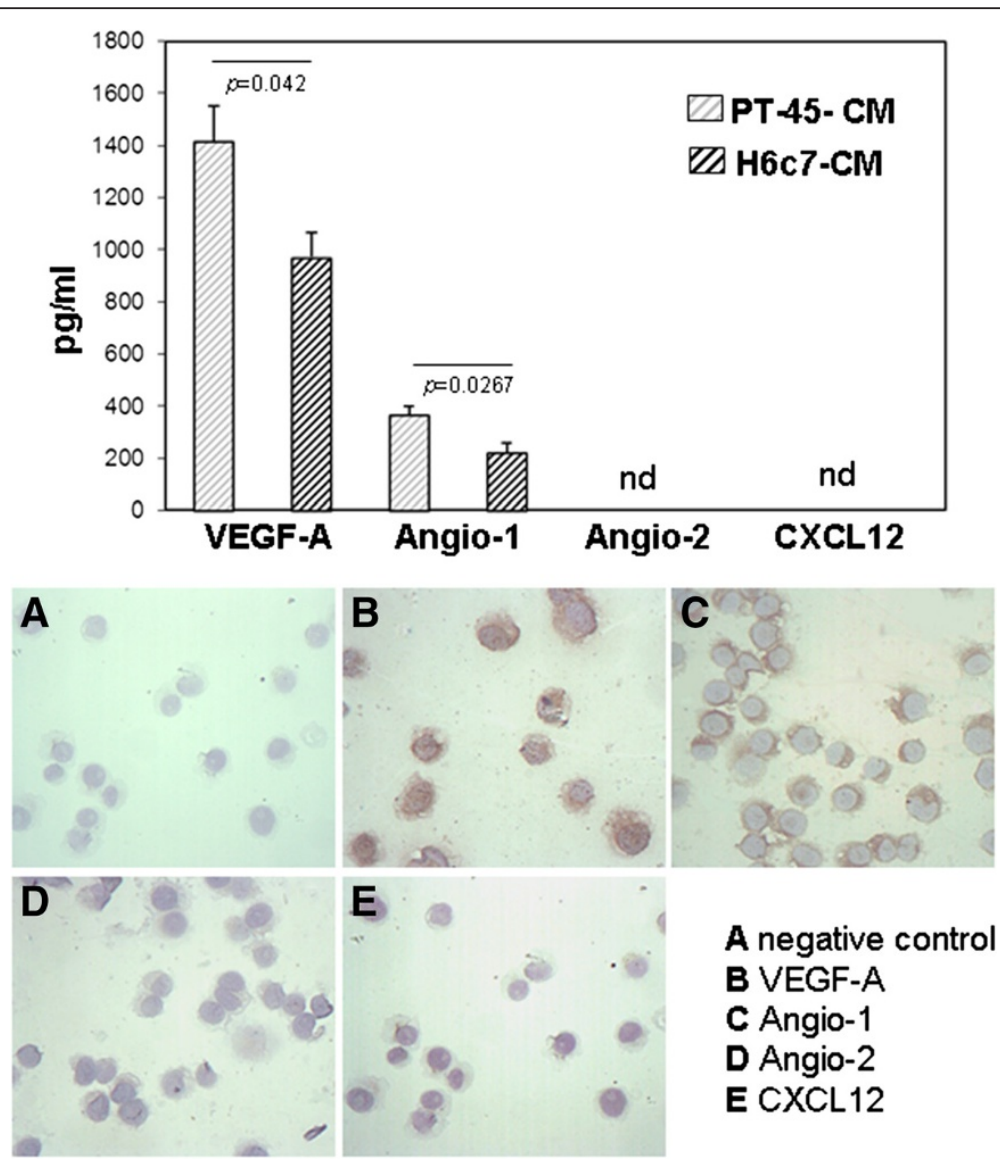

Figure 1 Concentrations of VEGF-A, Angio-1, Angio-2 and CXCL12 in CM derived from PT45 and H6c7 cell lines measured by ELISA. Values are means \pm SE of angiogenic factors detected in duplicate CM samples, in five separate experiments for PT45-CM, and in three for H6C7-CM (upper panel). Detection of VEGF-A, Angio-1, Angio-2 and CXCL12 in pancreatic carcinoma cells PT45, determined by immunohistochemistry. A representative negative control is also shown (original magnification 250X) (lower panel). 


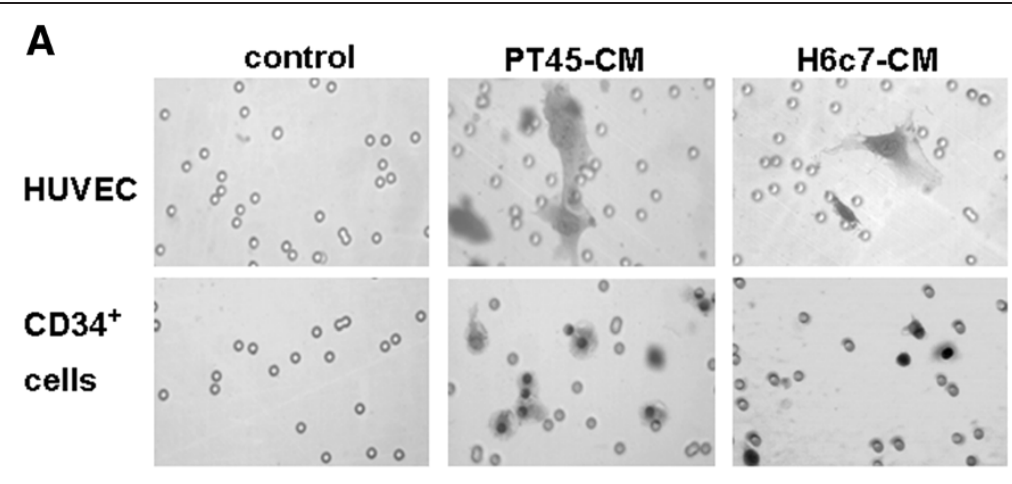

\section{B

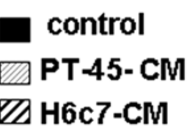

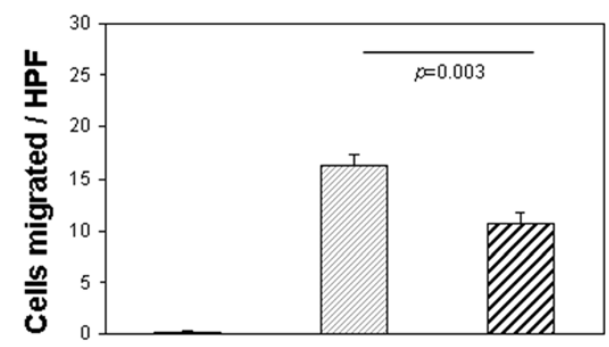
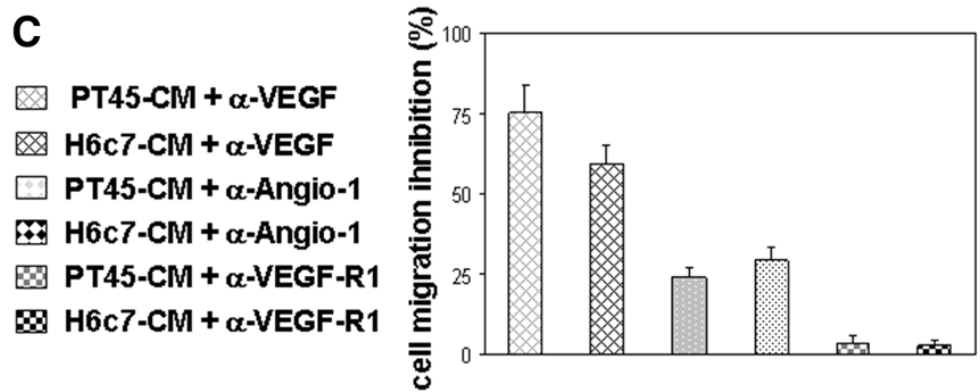

Figure 2 Chemo-attraction of CD34 ${ }^{+}$cells by PT45-CM and H6c7-CM. PB CD34 ${ }^{+}$cells and HUVEC were seeded into the upper compartment of a chemotaxis chamber. PT45- or H6C7-CM (30\%) was placed in the lower compartment, as such or pre-treated with neutralizing anti-VEGF-A and anti-Angio-1 antibodies. In selected experiments, CD34 ${ }^{+}$cells were pre-treated with a neutralizing anti-VEGF-R1 antibody before exposure to PT45- or to H6c7-CM. After 24 hr incubation, cells in the upper compartment were removed, and the number of CD34 ${ }^{+}$or HUVEC cells that had migrated from the upper compartment through the filter into the lower compartment was determined, by counting the cells in three random high-power fields. (A) Representative images of HUVEC and CD34 ${ }^{+}$cells migrating in response to medium alone (control), to PT45-CM or to H6c7-CM, in a transwell migration assay. (B) Number of cells migrating in a transwell migration assay, in the absence or presence of PT45-CM or H6C7-CM. Results are mean values \pm SE of six separate series of studies for PT45-CM and of three series for H6c7-CM. (C) Inhibitory effect of a neutralizing anti-VEGF-R1 antibody on $\mathrm{CD}_{3} 4^{+}$cell chemotaxis; values are expressed as percentage inhibition of $\mathrm{CD}_{3} 4^{+}$cell migration in the presence of PT45-CM/H6C7-CM versus medium alone (control). Data shown are means \pm SE from three separate series.

CM, 3.594 $\pm 5.843 \% ; H 6 c 7-C M, 2.891 \pm 2.3 \%)$. Inclusion of the isotype control antibodies had no effect (data not shown). These results demonstrate that, both in normal and in neoplastic conditions, the chemoattractant activity exerted by $\mathrm{H} 6 \mathrm{c} 7$ cells on $\mathrm{CD} 34^{+}$cells is mainly due to VEGF, and that the responding cells are included in the $\mathrm{CD} 34^{+} / \mathrm{VEGF}-\mathrm{R} 2^{+}$progenitor cell subset.

\section{Morphological changes of CD34 ${ }^{+}$cells cultured in the presence of PT45-CM}

The finding that the $\mathrm{CD}^{+} 4^{+}$cell subset is recruited by PT45-CM, along with the higher tumor-derived levels of VEGF-A and Angio-1 that play prominent roles in the vascularization process, prompted us to investigate whether tumor cells might cause differentiation of these $\mathrm{CD}_{3} 4^{+}$progenitor cells along the myeloid lineage to be switched toward the endothelial cell lineage. This was investigated by culturing purified normal $\mathrm{PB} \mathrm{CD} 34^{+}$cells for 19 days, under experimental conditions recognized as supporting their differentiation into myeloid cells (IL-3, SCF and GM-CSF) [27], but in the presence or absence of PT45-CM. The hypothesis that tumor-CM was actively altering the differentiation of $\mathrm{CD}^{+} 4^{+}$cells was initially supported by morphological evaluation of the resulting cells: as shown in Figure 3, in control cultures, the cells that developed from the CD $34^{+}$cells tended to be rounded. By contrast, in cultures with tumor-CM, a 


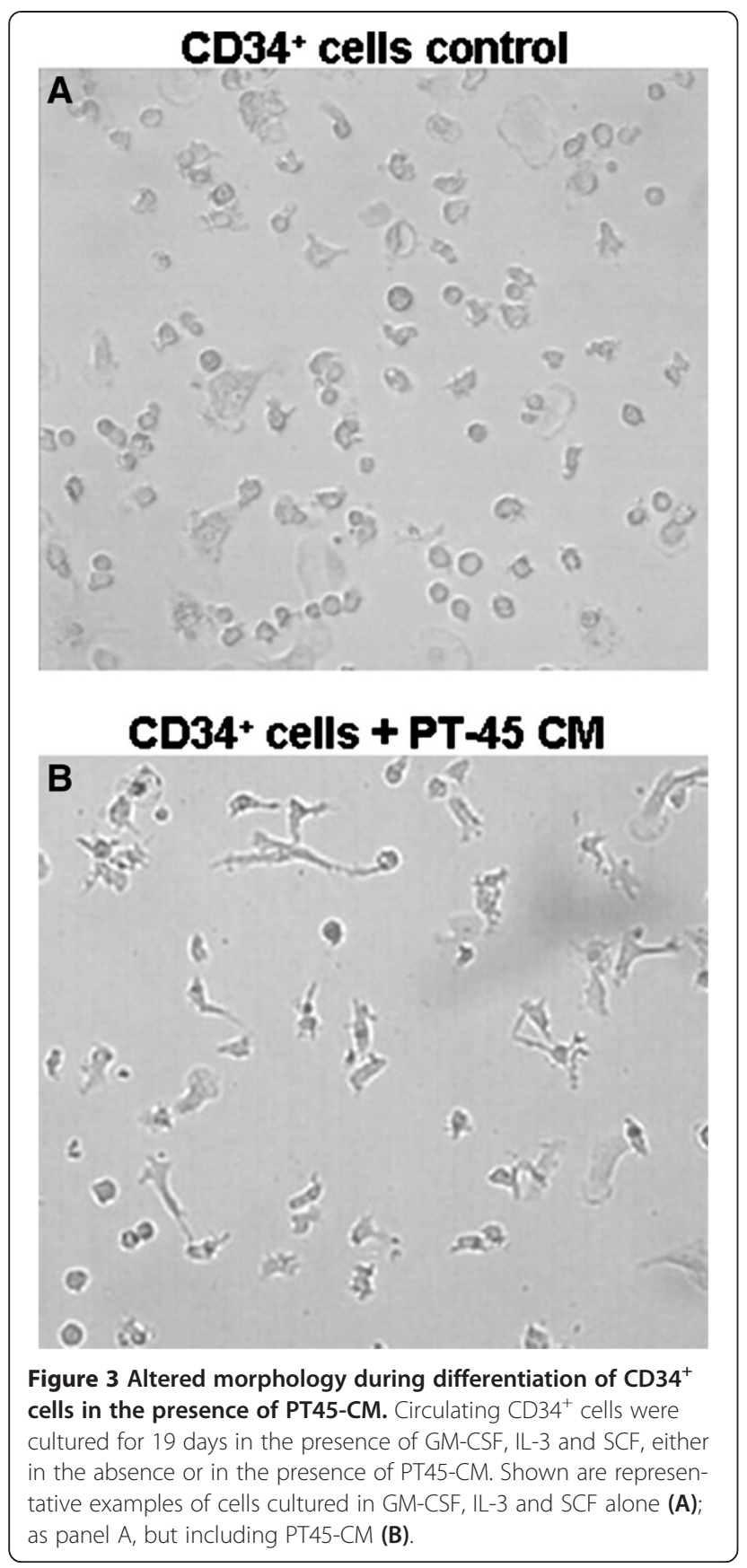

number of cells (median 7\%, range 4-18) appeared more elongated, spindle-shaped, with areas within the culture containing cells organized in long head-to-tail configurations.

\section{Characterization of $\mathrm{CD}_{3} 4^{+}$cultured in the presence of PT45-CM}

Tests were then run to determine whether or not endothelial cells develop in cultures containing PT45-CM, by means of uptake of Dil-AcLDL and Ulex europeus lectin binding; these activities are characteristic of endothelial cells $[28,29]$. We assayed these capacities in the 19-day cultures, by both double immunofluorescence staining and LSCM. We identified and quantified a small proportion (9-15\%) of cells showing double-positive staining for Dil-AcLDL uptake and binding of Ulex europeus lectin (Figure 4). These results indicate that this endothelial-like fraction originates in the hematopoietic stem-cell-containing $\mathrm{CD}_{3} 4^{+}$cell population only in the presence of tumor-CM.

Quantitative analysis of mRNA expression of VE-cadherin, vWF, VEGF-R1 and VEGF-R2

Using real timeRT-PCR, the expression of genes correlated with endothelial cell lineage differentiation was then evaluated, in $\mathrm{CD}_{3} 4^{+}$cells cultured for 19 days in the presence of IL-3, GM-CSF and SCF, with or without 30\% PT45-CM. The results, shown in Figure 5, demonstrate that $V E$-cadherin, $v W F$ and in particular the VEGF-R1 (flt-1) transcripts were more strongly expressed in $\mathrm{CD}_{3} 4^{+}$cells cultivated in the presence of PT45-CM, versus controls $(p=0.03, p=0.03$ and $p=$ 0.02 , respectively). Conversely, the expression of $V E G F-R 2$ [KDR or $f l k-1]$ was not significantly modulated in the presence of PT45-CM.

\section{Expression of endothelial-cell markers on $\mathrm{CD} 34^{+}$cells cultured in the presence of PT45-CM}

Cells derived from CD34 ${ }^{+}$cells cultured for 19 days with or without PT45-CM, under conditions that support myeloid differentiation, were analyzed for endothelialcell-marker expression, by flow cytometry (CD146 and CD105) and by immunohistochemistry (vWF and VEcadherin). As shown in Table 4, in the absence of tumor-CM, a small proportion of cells were positive for CD146 and CD105. However, when PT45-CM was also added to the $\mathrm{CD}_{3}{ }^{+}$cell cultures, a significantly greater number of cells expressed CD146 and CD105 ( $\mathrm{p}=0.003$ and $\mathrm{p}=0.006$, respectively,). As shown in Figure 6, exposure to tumor-derived angiogenic factors promoted the expression of VE-cadherin and vWF, both of which are endothelial-specific markers, in a subset of cultured CD $34^{+}$cells ( $24 \pm 8 \%$ and $23 \pm 10 \%$, respectively).

\section{In vitro angiogenesis assays}

Using an in vitro angiogenesis assay on Matrigel, the angiogenic potential of HUVEC was compared to that of untreated or PT45-CM-treated CD34 ${ }^{+}$cells, cultured for 19 days in the presence of IL-3, GM-CSF and SCF. Figure 7 A-E shows a representative tubulogenesis assay. On Matrigel, HUVEC formed a well-organized network of cordlike structures, with a median (range) angiogenic score of 2.19 (1.29-3.46) (E); conversely, in CD34 ${ }^{+}$cell control cultures, no endothelial organization was observed [median (range) angiogenic score: 0 (0-0.02)] (A). 


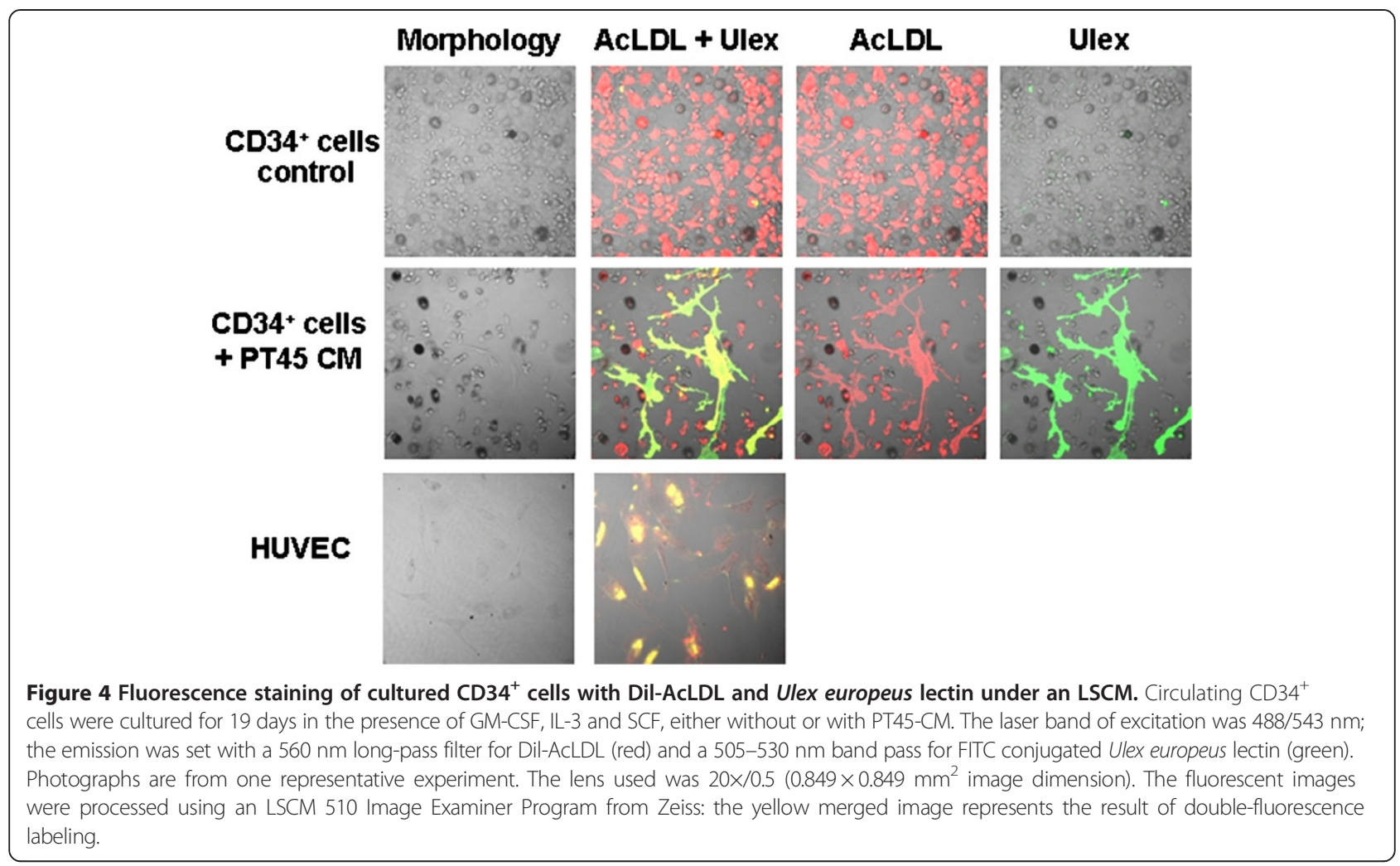

PT45-CM exposed CD34 ${ }^{+}$cells exhibited extended protrusions, connections, and alignments, but tube formation was less pronounced [median (range) angiogenic score of 1.47 (0.98-1.70), $p=0,002$ vs. HUVEC and $p<0.001$ vs. CD34 ${ }^{+}$ control cells] (B). The formation of capillary-like structures by PT45-CM treated $\mathrm{CD} 34^{+}$cells was significantly reduced by the use of a neutralizing anti-Angio-1 antibody [median

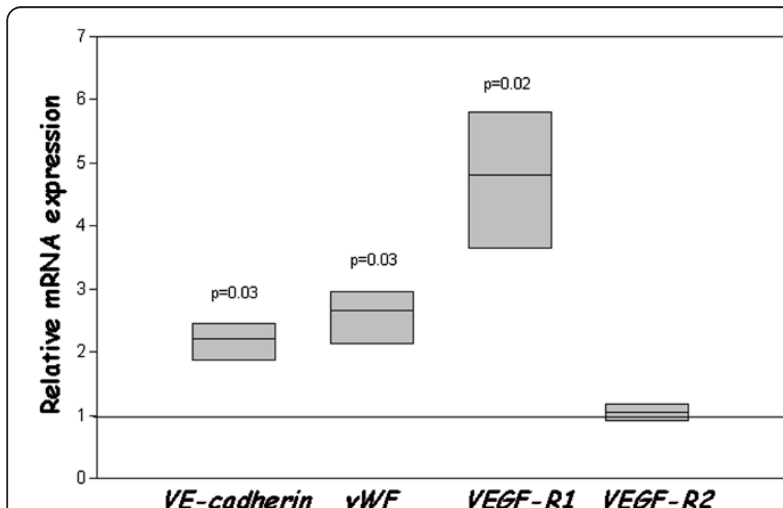

Figure 5 Levels of VE-cadherin, vWF, VEGF-R1 and VEGF-R2 mRNA in $\mathrm{CD}_{3} 4^{+}$cultured with or without PT45-CM. Cells were cultured for 19 days under conditions supporting their differentiation toward myeloid lineage cells, in the presence or absence of PT45-CM. Results were assessed by real time RT-PCR, and normalized to $\beta$-actin mRNA levels. Normalized gene expression values relative to that of control CD34 ${ }^{+}$cells (cultured in the absence of PT45-CM, arbitrarily set to 1) are shown. (range) angiogenic score of $0.45(0-1), p<0.001$ vs. PT45CM-exposed CD34 ${ }^{+}$cells] (C), but not when PT45-CM was pre-treated with a neutralizing anti-VEGF-A antibody [median (range) angiogenic score of 1.39 (0.20-1.72), $p=0.345$ vs. PT45-CM exposed CD34 $4^{+}$cells] (D). Nonimmune goat IgG did not affect cell organization (not shown).

\section{Discussion}

Expression of the CD34 surface antigen characterizes a heterogeneous population of BM-derived cells, including hematopoietic progenitor cells (HPC) and EPC [30], which can differentiate into mature endothelial cells when recruited to angiogenic sites. This in situ development of vessels, known as vasculogenesis, is prominent during embryonic development. However, although tissue remodeling and regeneration in postnatal life are mainly due to angiogenesis, involving preexisting vessels, it has recently been found that also vasculogenesis can occur in the adult, particularly during wound healing and tumor vascularization $[31,32]$. In cancer patients, including those with advanced pancreatic carcinoma, EPC are numerous compared to healthy controls; EPC numbers also correlate positively with circulating VEGF-A levels, and inversely with disease stage and prognosis $[17,33,34]$. These findings combine to suggest that tumor microenvironmental conditions may foster the recruitment, mobilization, and differentiation of EPC [35]. Both 
Table 4 Flow cytofluorimetric analysis of endothelial marker CD146 and CD105

\begin{tabular}{lcccc}
\hline $\begin{array}{l}\text { Colture conditions } \\
\text { of CD34 }\end{array}$ & \multicolumn{3}{c}{ \% positls } \\
\cline { 2 - 5 } & \multicolumn{3}{c}{ CD146 $\boldsymbol{p}^{\boldsymbol{a}}$ CD105 $\boldsymbol{p}$} \\
\hline GM-CSF, IL-3, SCF & $12.14 \pm 5.9$ & & $18.14 \pm 3$ & \\
GM-CSF, IL-3, SCF + & $21.84 \pm 7.7$ & 0.003 & $28.1 \pm 2.1$ & 0.006 \\
$\mathbf{3 0 \% ~ P T 4 5 - C M ~}$ & & & & \\
\hline
\end{tabular}

${ }^{a}$ vs CD $34^{+}$cultured in the presence of IL-3, GM-CSF and SCF.

tumor cells themselves, and tumor-educated immune cells, locally secrete a broad spectrum of biologicallyactive factors that facilitate cancer growth.

In a previous study that examined an array of tumorderived cytokines affecting the immune response, we found that the poorly-differentiated pancreatic carcinoma cell line PT45 produced high levels of VEGF-A [10]. The present study shows that, among other relevant angiogenic factors including the angiopoietins and
CXCL12, PT45 cells also express Angio-1 mRNA and protein. However, these vasculogenic cytokines are not tumor-exclusive products, but are thought to be part of the complex milieu involved in maintaining the vasculature in normal tissues: they are also expressed, albeit to a lesser extent, in the near-normal HPDE H6c7 cells. VEGF-A, released by both malignant (PT45) and normal (H6c7) cells, appears to play a major role, with regard to cell targets $\left(\mathrm{CD}_{3} 4^{+}\right.$VEGF-R2 $\left.{ }^{+}\right)$and functional chemotactic activity.

Unlike the physiological restoration of vascular perfusion to damaged tissues, blood vessel development in solid tumors is not closely controlled, but continues relentlessly. Tumors exploit a number of strategies to achieve vascularization (alteration of local normal equilibrium of anti and pro-angiogenic stimuli, co-optation of pre-existing vessels, stimulation of intussusceptive microvascular growth, post-natal vasculogenesis, and/or

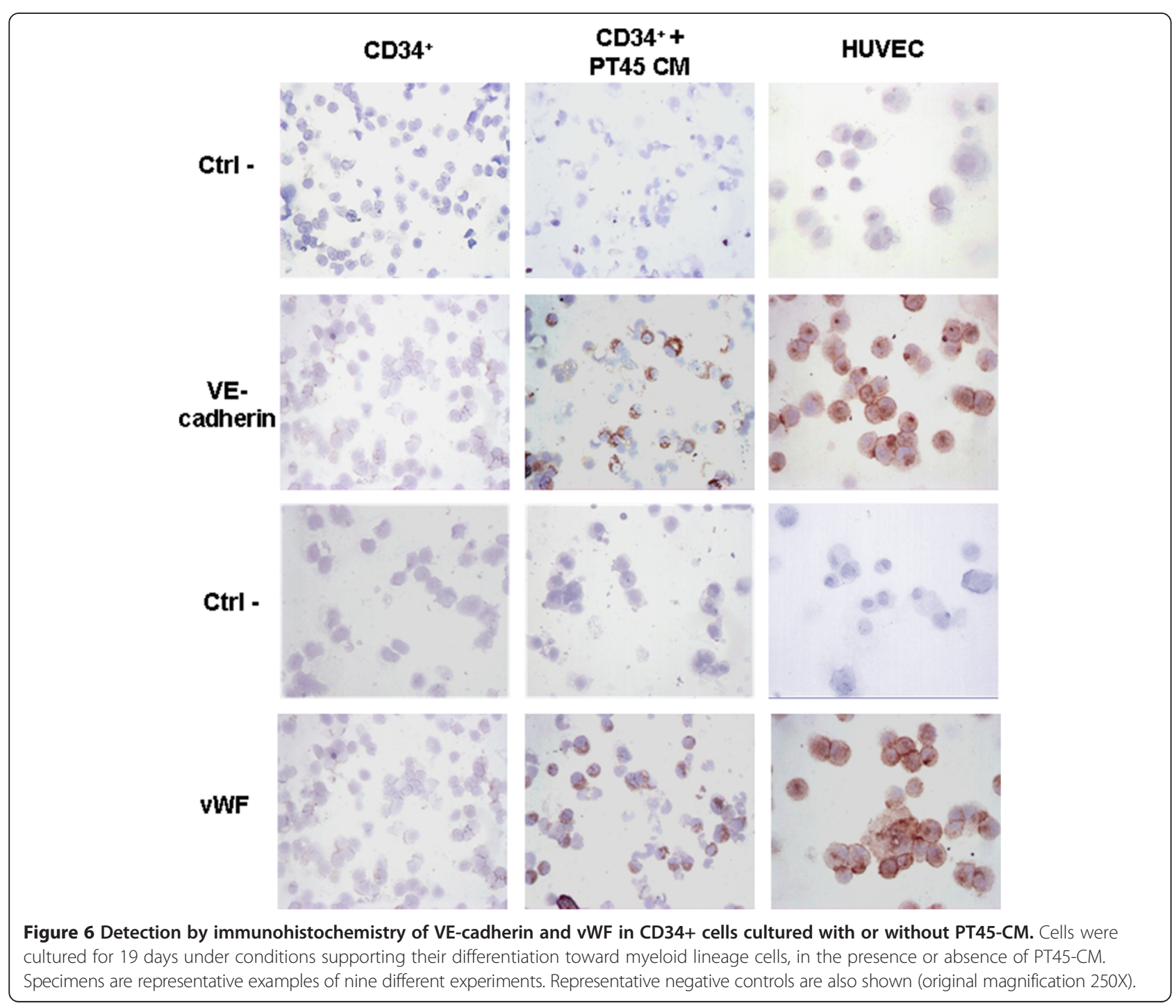



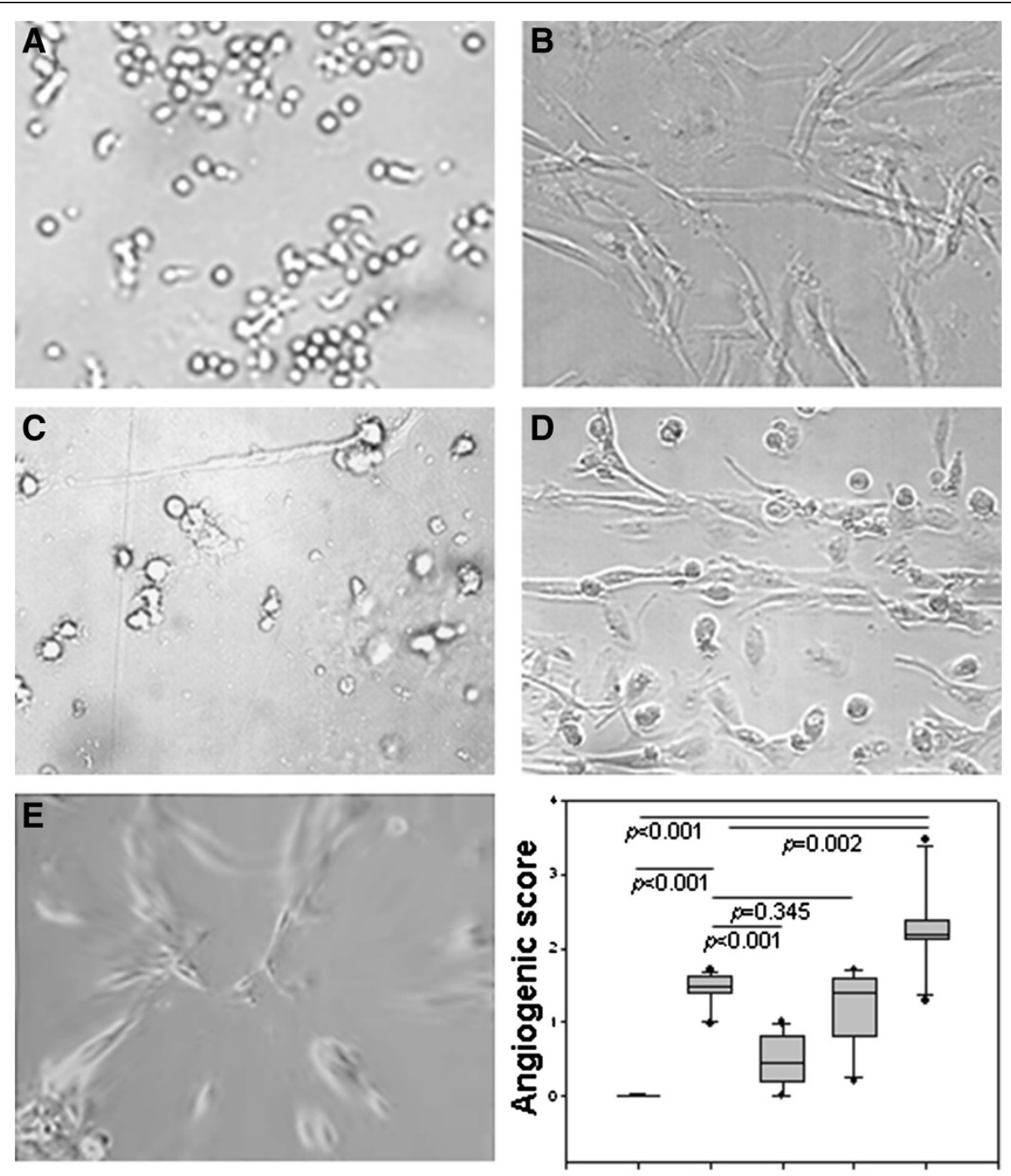

\section{A CD34+ cells control $\mathrm{B} \mathrm{CD34}+$ cells + PT $45 \mathrm{CM}$ \\ C CD34+ cells + PT $45 \mathrm{CM}+$ a-Angio -1 D CD34+ cells + PT-45 CM + a-VEGF-A E HUVEC}

Figure 7 In vitro angiogenic potential of PT45-CM treated CD34+ cells. CD34 ${ }^{+}$cells were grown on Matrigel for 24 h, after being cultured for 19 days under conditions supporting their differentiation toward myeloid lineage cells, in the absence (A) or presence (B) of PT45-CM, pretreated or not with a neutralizing anti-Angio-1 antibody (C) and with a neutralizing anti-VEGF-A (D) antibody. HUVEC (E) were used as positive control. The figure is representative of three experiments done in duplicate; the results are presented as median (range) values of the angiogenic numerical score, derived from the formula reported in the Materials and Methods section.

vasculogenic mimicry) [36], that have profound consequences on tumor growth, metastasis, and response to therapy. It thus appears possible that pancreatic tumor cells, influenced by their microenvironment, might also exploit abnormal levels of normally-beneficial angiogenic factors, such as VEGF and Angio-1, as one strategy to achieve vascularization.
The present study shows that, presumably thanks to an abnormally elevated gradient of angiogenic growth factors, medium conditioned by PT45 pancreatic carcinoma cells affects differentiation of a subset of CD34 $4^{+}$ cells into endothelial cells, producing conditions that support their differentiation toward myeloid lineage cells [27]. It is well-known that the high levels of VEGF 
produced by tumors can mobilize BM-derived stem cells in the peripheral circulation, and enhance their recruitment to the tumor vasculature [37,38]. Moreover, Angio-1 modulates several aspects of angiogenesis, including remodeling and vascular permeability, and, in conjunction with VEGF, it also plays an essential role in promoting the survival of endothelial and hematopoietic progenitor cells [39]. We show here the existence of a subpopulation of $\mathrm{CD}^{+} 4^{+}$cells $(10-15 \%)$ that, cultured under pro-myeloid differentiative conditions in the presence of PT45-CM, acquire what are often referred to as "endothelial cell lineage markers", namely spindle shape, incorporation of Dil-AClDl, and binding to Ulex-lectin $[28,29]$. This suggests that, among CD $34^{+}$cells, endothelial stem cells/progenitor cells may exist. In general, early EPC in the BM, or immediately after their migration into the systemic circulation, are positive for CD133/CD34/VEGF-R2, whereas circulating EPC are positive for CD34/VEGF-R2/CD31 [40]. This indicates that at least two types of EPC are simultaneously present in the peripheral blood, and that the cells can change their progenitor properties while in the circulation. However, since purified $\mathrm{CD} 34^{+}$cells were concomitantly cultured in the presence of IL-3, SCF and GM-CSF (all of which are survival and/or myeloid differentiation factors) it cannot be ruled out that these cells might originate from the monocyte/macrophage lineage, as other reports have suggested [41,42]. Although it has been suggested that myeloid cells may express specific endothelial markers (such as CD34, CD31 and VEGF-R2), and that they may localize adjacent to blood vessels, and differentiate into endothelial cells $[43,44]$, this hypothesis remains controversial; further research will be needed to clarify the situation.

In the present study, mRNA of both Flt-1 and KDR (genes encoding, respectively, for VEGF-R1 and VEGFR2) were detected in untreated $\mathrm{CD} 34^{+}$cells. After 19 days' culture in the presence of IL-3, SCF and GMCSF, with 30\% PT45-CM, the Flt-1 transcript significantly increased, while $K D R$ was unchanged. In a study on angiogenic-defective tumor-resistant Id-mutant mice, the restoration of tumor angiogenesis, after transplantation of wild-type BM or VEGF-mobilized stem cells, was associated not only with the uptake of BM-derived VEGF-R2 $2^{+}$-endothelial precursor cells in the blood vessels, but also with the incorporation of BM-derived myeloid cells into perivascular sites of the tumor microenvironment, these cells being characterized by the expression of VEGF-R1 [45]. It has been suggested that VEGF- $1^{+}$cells may differentiate into pericyte-like cells and play a role similar to pericytes in the tumor microenvironment [46].

It may, thus, be speculated that VEGF release by PT45 cells might concomitantly promote $\mathrm{CD} 34^{+}$VEGF-R2 ${ }^{+}$ cell differentiation along the endothelial lineage, this differentiation being characterized by the expression of vWF and VE-cadherin [47]. VEGF release might also induce the appearance of pericyte-like CD34 ${ }^{+}$VEGF-R $1^{+}$ cells, which play mutually-supporting roles in tumorvessel neoformation and stabilization, respectively. This hypothesis is supported by the finding that, after exposure for 19 days to PT45-CM in the presence of IL-3, SCF and GM-CSF, some CD34 ${ }^{+}$cells began to express specific endothelial markers, namely CD146, CD105, VE-cadherin and vWF, and a subset of cells started to express VEGF-R1 RNAm. Interestingly, in human tissues from patients with malignancies, VEGF-R $1^{+}$cell clusters have been observed in both primary tumor and metastatic tissue; increased numbers of $\mathrm{VEGF}-\mathrm{R}^{+}{ }^{+}$clusters have also been found at common sites of metastasis even before tumor spread, suggesting this tissue might be a potential future site for metastasis [48]. PT45 cells also produce and release Angio-1, the natural ligand for tunica internal endothelial cell kinase (Tie)-2 receptor, [49] which, in conjunction with VEGF, modulates some aspects of angiogenesis, including remodeling and vascular permeability [50].

In our study, a subset of CD34 $4^{+}$cells, cultured under conditions that support their differentiation toward myeloid lineage cells, acquired expression of Tie-2 (data not shown) whether or not the culture medium comprised PT45-CM. Interest in cells of the myeloid lineage in regard to tumor angiogenesis has recently been revived, thanks to the observation that tumor-infiltrating Tie-2expressing monocytes (TEM) convey pro-angiogenic programs in mouse models. TEM preferentially reside around newly formed tumor blood vessels in viable tumor areas [51,52]. It may thus be speculated that tumor-derived Angio-1 not only has a direct effect on endothelial cell behavior during vascular remodeling, but may also play a role in maintaining interactions between endothelial cells and support cells.

Since completing the tumor vasculogenesis process involves aligning endothelial cells and forming a threedimensional network of tubes incorporating a functional microvasculature, it was also evaluated whether $\mathrm{CD} 34^{+}$ cultured in Matrigel, in the presence of IL-3, SCF and GM-CSF with or without PT45-CM, could organize into a capillary-like structure. $\mathrm{CD} 34^{+}$cells, pre-exposed to PT45-CM, appeared markedly flattened; they migrated throughout the Matrigel surface and formed a network of interconnecting cells. Conversely, non-pre-exposed $\mathrm{CD}^{+}{ }^{+}$cells were small, round in shape, and did not spread. The fact that the introduction of an anti-Angio-1 blocking antibody caused the $\mathrm{CD}^{+} 4^{+}$cells to remain grouped suggests that Angio-1, released by PT45 cells, favors the formation of capillary-like structures, while VEGFA apparently has no effect on endothelial organization. 
Particularly controversial points in the relevance of vasculogenesis to cancer progression are whether EPC are mobilized in response to cytokine release, either by tumor cells or by damaged tissues/host immune cells, and whether the role of EPC in angiogenesis is merely regulatory, or whether they form part of the new tumor vasculature [53]. Our study shows that circulating EPC may be chemo-attracted, and develop into endotheliallike cells that can form cord-like structures in vitro, under the direction of factors released by pancreatic tumor cells. This might clarify the processes whereby pancreatic-tumor-mobilized EPC contribute to vessel formation, and in any case adds a possible explanation for the observation of increased circulating EPC in pancreatic carcinoma [10].

Blocking recruitment of EPC may be essential in order to overcome their negative consequences in terms of patient survival. Preclinical and clinical evidence suggests an association between treatment with certain drugs (including 5-fluouracil, the drug most commonly used to treat advanced/metastatic pancreatic cancer) and increased levels of BM-derived EPC and VEGF-R1 ${ }^{+}$cells; these cells stimulate tumor progression and metastasis [54-56]. Other conventional drugs, such as gemcitabine and cisplatinum, show no similar association [57].

Numerous clinical trials employing antiangiogenic drugs for the treatment of pancreatic cancer have thus far failed to produce improvements in treatment [58]. One of the possible mechanisms underlying this general resistance is poor tissue perfusion, which limits drug delivery. Olive et al. provided evidence that, in KRAS and p53 mutant pancreatic adenocarcinoma xenografts in a gemcitabine-resistant mouse model, chemotherapy does not reach tumor cells due to poor tumor vascularization [59]. Approaches involving antiangiogenic therapy are thus counterintuitive, given that destruction of the tumor vasculature might be expected to impair drug delivery.

Pancreatic carcinoma is generally surrounded by dense fibro-inflammatory tissue that creates unusually high interstitial fluid pressure (IFP); this high pressure collapses the tumor blood vessels, limiting access by, and efficacy of, conventional forms of chemotherapy [60]. In genetically-engineered mouse models of pancreatic adenocarcinoma, which mimic the clinical syndrome, histopathology, and molecular progression of the human disease, combined enzymatic degradation of hyaluronan and cytotoxic therapy leads to a rapid reduction of the IFP, accompanied by remodeling of the standard cytotoxic delivery; this combined approach thus holds promise as a therapeutic strategy [61].

On the basis of these studies, and in consideration of the complex role of tumor vascularization in relations between chemotherapic drugs and tumor cells, treatment approaches involving targeting angiogenesis and vasculogenesis should be evaluated with extreme care.

\section{Conclusions}

This study demonstrates the ability of pancreatic carcinoma cells to attract $\mathrm{CD} 34^{+}$cells to the tumor site, and to interfere with those cells' hematopoietic development, by diverting their differentiation toward endothelial cells; these cells can become a component of the tumor vasculature. A better understanding of cancer-associated molecular mechanisms involved in favoring the vasculogenesis process in pancreatic carcinoma could therefore provide important knowledge to design new and more effective ways of combining anti-angiogenic drugs with established chemotherapies, the goal being to prevent angiogenic escape or invasion.

\section{Abbreviations}

VEGF: Vascular endothelial growth factor; EPC: Endothelial progenitor cells; BM: Bone marrow; Angio: Angiopoietin; FCS: Fetal calf serum; CM: Conditioned medium; HUVEC: Human umbilical vein endothelial cells; IL: Interleukin; SCF: Stem cell factor; GM-CSF: Granulocyte-macrophage colony stimulating factor; LSCM: Laser scanning confocal microscopy; Dil-ACLDL: 1,1-dioctadecyl-3,3,3,3-tetramethilindocarbocyanine-labeled acetylated low-density lipoprotein; FITC: Fluorescein isothiocyanate.

\section{Competing interests}

The authors declare that they have no competing interests.

\section{Authors' contributions}

BV carried out all flow cytometry, real time RT-PCR, and LSCM analyses, participated in data analysis, and helped to draft several chapters of the manuscript; FB provided expertise on LSCM study and was involved in the discussion of the results and manuscript preparation; TS performed immunomagnetic separation and cultures of $\mathrm{CD} 34^{+}$cells, AN carried out statistical analysis of the data; AP was involved in cytospin preparations and IHC analysis; LC, GM, GP participated in discussion of the data and preparation of the manuscript; GB conceived of and designed the study, coordinated the work, carried out experiments on Matrigel, and prepared the manuscript. All authors read and approved the final manuscript.

\section{Acknowledgements}

This work was supported by Piedmont Regional Government to GB. We would also like to express our gratitude to Dr. Ming-Sound Tsao (Ontario Cancer Institute/Princess Margaret Hospital) and its Institution (University of Health Network, Toronto, Canada) for providing us with the immortalized human pancreatic duct epithelial cells $\mathrm{H} 6 \mathrm{c} 7$ used to complete this work.

\section{Author details}

${ }^{1}$ Department of Medical Sciences, University of Turin, Turin, Italy. ${ }^{2}$ Department of Clinical and Biological Sciences, University of Turin, Turin, Italy. ${ }^{3}$ Department of Medical Oncology, Azienda Ospedaliera Città della Salute e della Scienza di Torino, Turin, Italy.

Received: 4 April 2013 Accepted: 7 December 2013

Published: 17 December 2013

\section{References}

1. Bergers $G$, Benjamin LE: Tumorigenesis and the angiogenic switch. Nat Rev Cancer 2003, 3:401-410.

2. Coussens LM, Werb Z: Inflammation and cancer. Nature 2002, 420:860-867.

3. Ferrara N: Vascular endothelial growth factor: basic science and clinical progress. Endocr Rev 2004, 25:581-611.

4. Mattern J, Koomagi R, Volm M: Association of vascular endothelial growth factor expression with intratumoral microvessel density and tumour cell 
proliferation in human epidermoid lung carcinoma. Br J Cancer 1996, 73:931-934.

5. Yoshiji H, Gomez DE, Shibuya M, Thorgeirsson UP: Expression of vascular endothelial growth factor, its receptor, and other angiogenic factors in human breast cancer. Cancer Res 1996, 56:2013-2016.

6. Brown LF, Berse B, Jackman RW, Tognazzi K, Manseau EJ, Senger DR, Dvorak HF: Expression of vascular permeability factor (vascular endothelial growth factor) and its receptors in adenocarcinomas of the gastrointestinal tract. Cancer Res 1993, 53:4727-4735.

7. Hartenbach EM, Olson TA, Goswitz JJ, Mohanraj D, Twiggs LB, Carson LF, Ramakrishnan S: Vascular endothelial growth factor (VEGF) expression and survival in human epithelial ovarian carcinomas. Cancer Lett 1997 121:169-175.

8. Tokunaga T, Oshika Y, Abe Y, Ozeki Y, Sadahiro S, Kijima H, Tsuchida T, Yamazaki H, Ueyama Y, Tamaoki N, Nakamura M: Vascular endothelial growth factor (VEGF) mRNA isoform expression pattern is correlated with liver metastasis and poor prognosis in colon cancer. Br J Cancer 1998, 77:998-1002.

9. Kim KJ, Li B, Winer J, Armanini M, Gillett N, Phillips HS, Ferrara N: Inhibition of vascular endothelial growth factor-induced angiogenesis suppresses tumour growth in vivo. Nature 1993, 362:841-844.

10. Bellone G, Carbone A, Smirne C, Scirelli T, Buffolino A, Novarino A, Stacchini A, Bertetto O, Palestro G, Sorio C, et al: Cooperative induction of a tolerogenic dendritic cell phenotype by cytokines secreted by pancreatic carcinoma cells. J Immunol 2006, 177:3448-3460.

11. Bellone G, Smirne C, Mauri FA, Tonel E, Carbone A, Buffolino A, Dughera L, Robecchi A, Pirisi M, Emanuelli G: Cytokine expression profile in human pancreatic carcinoma cells and in surgical specimens: implications for survival. Cancer Immunol Immunother 2006, 55:684-698.

12. Itakura J, Ishiwata T, Friess H, Fujii H, Matsumoto Y, Buchler MW, Korc M: Enhanced expression of vascular endothelial growth factor in human pancreatic cancer correlates with local disease progression. Clin Cancer Res 1997, 3:1309-1316.

13. Seo Y, Baba H, Fukuda T, Takashima M, Sugimachi K: High expression of vascular endothelial growth factor is associated with liver metastasis and a poor prognosis for patients with ductal pancreatic adenocarcinoma. Cancer 2000, 88:2239-2245.

14. Ikeda N, Adachi M, Taki T, Huang C, Hashida H, Takabayashi A, Sho M, Nakajima Y, Kanehiro $\mathrm{H}$, Hisanaga M, et al: Prognostic significance of angiogenesis in human pancreatic cancer. Br J Cancer 1999, 79:1553-1563.

15. Gerhardt H, Golding M, Fruttiger M, Ruhrberg C, Lundkvist A, Abramsson A, Jeltsch M, Mitchell C, Alitalo K, Shima D, Betsholtz C: VEGF guides angiogenic sprouting utilizing endothelial tip cell filopodia. J Cell Biol 2003, 161:1163-1177.

16. Ding YT, Kumar S, Yu DC: The role of endothelial progenitor cells in tumour vasculogenesis. Pathobiology 2008, 75:265-273.

17. Vizio B, Novarino A, Giacobino A, Cristiano C, Prati A, Brondino G, Ciuffreda $\mathrm{L}$, Bellone G: Pilot study to relate clinical outcome in pancreatic carcinoma and angiogenic plasma factors/circulating mature/progenitor endothelial cells: preliminary results. Cancer Sci 2010, 101:2448-2454.

18. Stoll BR, Migliorini C, Kadambi A, Munn LL, Jain RK: A mathematical model of the contribution of endothelial progenitor cells to angiogenesis in tumors: implications for antiangiogenic therapy. Blood 2003, 102:2555-2561.

19. Kalthoff H, Schmiegel W, Roeder C, Kasche D, Schmidt A, Lauer G, Thiele HG, Honold G, Pantel K, Riethmuller G, et al: p53 and K-RAS alterations in pancreatic epithelial cell lesions. Oncogene 1993, 8:289-298.

20. Furukawa T, Duguid WP, Rosenberg L, Viallet J, Galloway DA, Tsao MS: Long-term culture and immortalization of epithelial cells from normal adult human pancreatic ducts transfected by the E6E7 gene of human papilloma virus 16. Am J Pathol 1996, 148:1763-1770.

21. Ouyang H, Mou L, Luk C, Liu N, Karaskova J, Squire J, Tsao MS: Immortal human pancreatic duct epithelial cell lines with near normal genotype and phenotype. Am J Pathol 2000, 157:1623-1631

22. Ramakers C, Ruijter JM, Deprez RH, Moorman AF: Assumption-free analysis of quantitative real-time polymerase chain reaction (PCR) data. Neurosci Lett 2003, 339:62-66.

23. Rasmussen R: Quantification on the LightCycler. In Rapid Cycle Real-time PCR, Methods and Applications. Edited by Meuer S, Wittwer C, Nakawarw K. Heidelberg: Springer Press; 2001:21-34.

24. Pfaffl MW, Horgan GW, Dempfle L: Relative expression software tool (REST) for group-wise comparison and statistical analysis of relative expression results in real-time PCR. Nucleic Acids Res 2002, 30:e36.
25. Takahashi T, Kalka C, Masuda H, Chen D, Silver M, Kearney M, Magner M, Isner JM, Asahara T: Ischemia- and cytokine-induced mobilization of bone marrow-derived endothelial progenitor cells for neovascularization. Nat Med 1999, 5:434-438.

26. Pomyje J, Zivny J, Sefc L, Plasilova M, Pytlik R, Necas E: Expression of genes regulating angiogenesis in human circulating hematopoietic cord blood CD34+/CD133+ cells. Eur J Haematol 2003, 70:143-150.

27. Lotem J, Sachs L: Cytokine control of developmental programs in normal hematopoiesis and leukemia. Oncogene 2002, 21:3284-3294.

28. Voyta JC, Via DP, Butterfield CE, Zetter BR: Identification and isolation of endothelial cells based on their increased uptake of acetylated-low density lipoprotein. J Cell Biol 1984, 99:2034-2040.

29. Holthofer $H$, Virtanen I, Kariniemi AL, Hormia M, Linder E, Miettinen A: Ulex europaeus I lectin as a marker for vascular endothelium in human tissues. Lab Invest 1982, 47:60-66.

30. Asahara T, Murohara T, Sullivan A, Silver M, van der Zee R, Li T, Witzenbichler B, Schatteman $\mathrm{G}$, Isner JM: Isolation of putative progenitor endothelial cells for angiogenesis. Science 1997, 275:964-967.

31. Wong W, Crawford JD: Vasculogenic cytokines in wound healing. BioMed Res Intern 2013, 2013:190486

32. Tepper OM, Capla JM, Galiano RD, Ceradini DJ, Callaghan MJ, Kleinman ME, Gurtner GC: Adult vasculogenesis occurs through in situ recruitment, proliferation, and tubulization of circulating bone marrow-derived cells. Blood 2005, 105:1068-1077.

33. Igreja C, Courinha M, Cachaco AS, Pereira T, Cabecadas J, da Silva MG, Dias S: Characterization and clinical relevance of circulating and biopsy-derived endothelial progenitor cells in lymphoma patients. Haematologica 2007, 92:469-477.

34. Naik RP, Jin D, Chuang E, Gold EG, Tousimis EA, Moore AL, Christos PJ, de Dalmas T, Donovan D, Rafii S, Vahdat LT: Circulating endothelial progenitor cells correlate to stage in patients with invasive breast cancer. Breast Cancer Res Tr 2008, 107:133-138.

35. Swartz MA, lida N, Roberts EW, Sangaletti S, Wong MH, Yull FE, Coussens LM, DeClerck YA: Tumor microenvironment complexity: emerging roles in cancer therapy. Cancer Res 2012, 72:2473-2480.

36. Bussolati B, Grange C, Camussi G: Tumor exploits alternative strategies to achieve vascularization. FASEB J 2011, 25:2874-2882.

37. Asahara T, Takahashi T, Masuda H, Kalka C, Chen D, Iwaguro H, Inai Y, Silver M, Isner JM: VEGF contributes to postnatal neovascularization by mobilizing bone marrow-derived endothelial progenitor cells. EMBO J 1999, 18:3964-3972

38. Hattori K, Dias S, Heissig B, Hackett NR, Lyden D, Tateno M, Hicklin DJ, Zhu Z, Witte L, Crystal RG, et al: Vascular endothelial growth factor and angiopoietin-1 stimulate postnatal hematopoiesis by recruitment of vasculogenic and hematopoietic stem cells. J Exp Med 2001, 193:1005-1014.

39. Huang $X L$, Takakura N, Suda T: In vitro effects of angiopoietins and VEGF on hematopoietic and endothelial cells. Biochem Bioph Res Co 1999, 264:133-138.

40. Hristov M, Erl W, Weber PC: Endothelial progenitor cells: mobilization, differentiation, and homing. Arterioscler Thromb Vasc Biol 2003, 23:1185-1189.

41. Rehman J, Li J, Orschell CM, March KL: Peripheral blood "endothelial progenitor cells" are derived from monocyte/macrophages and secrete angiogenic growth factors. Circulation 2003, 107:1164-1169.

42. Rookmaaker MB, Vergeer M, van Zonneveld AJ, Rabelink TJ, Verhaar MC: Endothelial progenitor cells: mainly derived from the monocyte/ macrophage-containing CD34- mononuclear cell population and only in part from the hematopoietic stem cell-containing CD34+ mononuclear cell population. Circulation 2003, 108:e150. author reply e150.

43. Rohde E, Malischnik C, Thaler D, Maierhofer T, Linkesch W, Lanzer G, Guelly C, Strunk D: Blood monocytes mimic endothelial progenitor cells. Stem Cells 2006, 24:357-367

44. Bailey AS, Willenbring $H$, Jiang $S$, Anderson DA, Schroeder DA, Wong MH, Grompe M, Fleming WH: Myeloid lineage progenitors give rise to vascular endothelium. P Natl Acad Sci Usa 2006, 103:13156-13161.

45. Lyden D, Hattori K, Dias S, Costa C, Blaikie P, Butros L, Chadburn A, Heissig B, Marks W, Witte $L$, et al: Impaired recruitment of bone-marrow-derived endothelial and hematopoietic precursor cells blocks tumor angiogenesis and growth. Nat Med 2001, 7:1194-1201

46. Gerhardt H, Betsholtz C: Endothelial-pericyte interactions in angiogenesis. Cell Tissue Res 2003, 314:15-23. 
47. Gehling UM, Ergun S, Schumacher U, Wagener C, Pantel K, Otte M, Schuch G, Schafhausen P, Mende T, Kilic N, et al: In vitro differentiation of endothelial cells from AC133-positive progenitor cells. Blood 2000, 95:3106-3112.

48. Kaplan RN, Psaila B, Lyden D: Bone marrow cells in the 'pre-metastatic niche': within bone and beyond. Cancer Meta Rev 2006, 25:521-529.

49. Davis $\mathrm{S}$, Aldrich $T H$, Jones PF, Acheson A, Compton DL, Jain V, Ryan TE, Bruno J, Radziejewski C, Maisonpierre PC, Yancopoulos GD: Isolation of angiopoietin-1, a ligand for the TIE2 receptor, by secretion-trap expression cloning. Cell 1996, 87:1161-1169.

50. Holash J, Maisonpierre PC, Compton D, Boland P, Alexander CR, Zagzag D, Yancopoulos GD, Wiegand SJ: Vessel cooption, regression, and growth in tumors mediated by angiopoietins and VEGF. Science 1999, 284:1994-1998.

51. De Palma M, Naldini L: Tie2-expressing monocytes (TEMs): novel targets and vehicles of anticancer therapy? Biochimica et Biophysica Acta 2009, 1796:5-10.

52. Squadrito ML, De Palma M: Macrophage regulation of tumor angiogenesis: implications for cancer therapy. Mol Aspects Med 2011, 32:123-145.

53. Nolan DJ, Ciarrocchi A, Mellick AS, Jaggi JS, Bambino K, Gupta S, Heikamp E, McDevitt MR, Scheinberg DA, Benezra R, Mittal V: Bone marrow-derived endothelial progenitor cells are a major determinant of nascent tumor neovascularization. Gene Dev 2007, 21:1546-1558.

54. Shaked Y, Ciarrocchi A, Franco M, Lee CR, Man S, Cheung AM, Hicklin DJ, Chaplin D, Foster FS, Benezra R, Kerbel RS: Therapy-induced acute recruitment of circulating endothelial progenitor cells to tumors. Science 2006, 313:1785-1787.

55. Furstenberger G, von Moos R, Lucas R, Thurlimann B, Senn HJ, Hamacher J, Boneberg EM: Circulating endothelial cells and angiogenic serum factors during neoadjuvant chemotherapy of primary breast cancer. Brit J Cancer 2006, 94:524-531.

56. Shaked Y, Kerbel RS: Antiangiogenic strategies on defense: on the possibility of blocking rebounds by the tumor vasculature after chemotherapy. Cancer Res 2007, 67:7055-7058.

57. Shaked $Y$, Henke E, Roodhart JM, Mancuso P, Langenberg MH, Colleoni M, Daenen LG, Man S, Xu P, Emmenegger U, et al: Rapid chemotherapyinduced acute endothelial progenitor cell mobilization: implications for antiangiogenic drugs as chemosensitizing agents. Cancer Cell 2008, 14:263-273

58. Mulder K, Koski S, Scarfe A, Chu Q, King K, Spratlin J: Antiangiogenic agents in advanced gastrointestinal malignancies: past, present and a novel future. Oncotarget 2010, 1:515-529.

59. Olive KP, Jacobetz MA, Davidson CJ, Gopinathan A, McIntyre D, Honess D, Madhu B, Goldgraben MA, Caldwell ME, Allard D, et al: Inhibition of Hedgehog signaling enhances delivery of chemotherapy in a mouse model of pancreatic cancer. Science 2009, 324:1457-1461.

60. Bouzin C, Feron O: Targeting tumor stroma and exploiting mature tumor vasculature to improve anti-cancer drug delivery. Drug Resist Updates 2007, 10:109-120.

61. Provenzano PP, Cuevas C, Chang AE, Goel VK, Von Hoff DD, Hingorani SR: Enzymatic targeting of the stroma ablates physical barriers to treatment of pancreatic ductal adenocarcinoma. Cancer Cell 2012, 21:418-429.

doi:10.1186/1479-5876-11-314

Cite this article as: Vizio et al:: Pancreatic-carcinoma-cell-derived proangiogenic factors can induce endothelial-cell differentiation of a subset of circulating CD34+ progenitors. Journal of Translational Medicine 2013 11:314.

\section{Submit your next manuscript to BioMed Central and take full advantage of:}

- Convenient online submission

- Thorough peer review

- No space constraints or color figure charges

- Immediate publication on acceptance

- Inclusion in PubMed, CAS, Scopus and Google Scholar

- Research which is freely available for redistribution 